\title{
Nymphal biology of Capnioneura gelesae Berthélemy \& Baena, 1984 (Plecoptera, Capniidae) in temporary streams of the Sierra Morena (southern Spain)
}

\author{
M.J. López-Rodríguez ${ }^{1, *}$, P. Delgado-Juan², J.M. Luzón-Ortega ${ }^{2}$ and J.M. Tierno de Figueroa ${ }^{2}$ \\ ${ }^{1}$ Departamento de Ecología, Facultad de Ciencias, Universidad de Granada, Campus Fuentenueva s/n, 18071, \\ Granada, Spain. \\ ${ }^{2}$ Departamento de Zoología, Facultad de Ciencias, Universidad de Granada, Campus Fuentenueva s/n, 18071, \\ Granada, Spain.
}

* Corresponding author: manujlr@ugr.es

Received: $26 / 10 / 16$

Accepted: 12/01/17

\begin{abstract}
Nymphal biology of Capnioneura gelesae Berthélemy \& Baena, 1984 (Plecoptera, Capniidae) in temporary streams of the Sierra Morena (southern Spain)

We present the results of a study of the life cycle and nymphal feeding of the stonefly Capnioneura gelesae Berthélemy \& Baena, 1984 in two temporary streams of the Sierra Morena (southern Iberian Peninsula). The species has a fast-seasonal univoltine life cycle at both sites, but the diet differs depending on the stream. Nymphs from one stream feed mainly on detritus, so they can be classified as gatherer-collectors from a trophic, functional point of view, and those from the other stream feed mainly on diatoms, behaving as scrapers. However, the study of the diet across the nymphal growth period shows a slight trend towards shredder behaviour in the largest nymphs from one population. When comparing these results with those from other Capnioneura species, we observe the existence of interspecific variability. The most similar species in terms of life cycle and feeding is C. petitpierreae Aubert, 1961, which is also an inhabitant of Mediterranean temporary streams.
\end{abstract}

Key words: Stoneflies, Capnioneura gelesae, life cycle, nymphal feeding, southern Iberian Peninsula.

\section{RESUMEN}

Biología ninfal de Capnioneura gelesae Berthélemy \& Baena, 1984 (Plecoptera, Capniidae) en arroyos temporales de Sierra Morena (sur de España)

Se presentan los resultados de un estudio sobre el ciclo de vida y la alimentación ninfal del plecóptero Capnioneura gelesae Berthélemy \& Baena, 1984 en dos arroyos temporales de Sierra Morena (sur de la península ibérica). La especie tiene un ciclo de vida univoltino estacional rápido en ambos sitios, pero la dieta de las ninfas es diferente dependiendo del arroyo. Las ninfas de uno de ellos se alimentan principalmente de detrito, así que puede ser clasificada como colectora de depósito desde un punto de vista trófico funcional, y las del otro lo hacen principalmente de diatomeas, comportándose como raspadoras. No obstante, el estudio de la dieta a lo largo del periodo de desarrollo ninfal muestra una ligera tendencia al comportamiento fragmentador en las ninfas de mayor tamaño de una población. Al comparar estos resultados con los existentes en otras especies de Capnioneura, se observa la existencia de variabilidad interespecífica. La especie más similar en cuanto a ciclo de vida y alimentación es $\mathrm{C}$. petitpierreae Aubert, 1961, también habitante de arroyos temporales mediterráneos.

Palabras clave: Plecópteros, Capnioneura gelesae, ciclo de vida, alimentación ninfal, sur de la península ibérica. 


\section{INTRODUCTION}

In the Palearctic region, Plecoptera is the aquatic insect order that is most often associated with running waters, usually living in permanent, clean, well-oxygenated and cold streams, but certain species have adapted to temporary water courses, as is the case for some Mediterranean stoneflies (Tierno de Figueroa et al., 2013). More than fifty years ago, Aubert (1963) described the thermophilous association (l'association thermophile) among stoneflies inhabiting temporary, warm and medium-low altitude streams, including species such as Hemimelaena flaviventris (Pictet, 1842), Brachyptera auberti Consiglio, 1957, Nemoura lacustris Pictet, 1865 and Tyrrhenoleuctra tangerina (Navás, 1922), among others. According to Hynes (1976), temporary streams can normally be inhabited by univoltine stonefly species, usually those with egg or nymphal diapause. Since then, and particularly within the last fifteen years, some studies have been conducted with the aim to better identify the biological traits allowing stoneflies to inhabit Mediterranean temporary streams. These studies have shown that Plecoptera have sufficient behavioural, ecological and physiological mechanisms to cope with potentially unfavourable conditions that may occur in temporary waters (Sanz et al., 2010). For example, due to the limited resource availability in temporary streams, nymphs of some species show unique feeding habits that are not common for their families (demonstrated both by the study of gut contents and by analyses of digestive enzymatic activities; López-Rodríguez et al., 2009b; Tierno de Figueroa et al., 2011b). In addition, egg development can be very fast, and the eggs of one species, Tyrrhenoleuctra minuta (Klapálek, 1901), are even fully developed when laid and hatch rapidly after laying, indicating a certain degree of ovoviviparism (López-Rodríguez et al., 2009a). Additionally, there are species with life cycles that last more than one year, undergoing a resting stage during the dry period, such as Guadalgenus franzi (Aubert, 1963) (Agüero-Pelegrín \& FerrerasRomero, 2002; López-Rodríguez et al., 2009b), and other species with a spring flight period and high secondary production, reaching a relatively large size over a short period of time (López-Rodríguez et al., 2009b) and with important enzymatic antioxidant potential (Sanz et al., 2010).

The genus Capnioneura Ris, 1905, within the family Capniidae, is distributed in the western Palearctic and includes 15 species, six of which are present in the Iberian Peninsula (DeWalt $e t$ al., 2016). Among the Iberian species, three, $C$. gelesae Berthélemy \& Baena, 1984, C. libera (Navás, 1909) and C. petitpierreae Aubert, 1961, are components of the thermophilous association (Tierno de Figueroa et al., 2003; Luzón-Ortega, 2002).

Data on the nymphal biology of the species belonging to this genus are scarce and limited to a few species in a few localities. Up to now, life cycle data exist only for species such as $C$. brachyptera Despax, 1932 in the Pyrenees (Lavandier, 1975), C. mitis Despax, 1932 in the Sierra Nevada (Spain) (Sánchez-Ortega \& AlbaTercedor, 1990; López-Rodríguez et al., 2008) and C. petitpierreae in Serranía de Ronda (Spain) (Navarro-Martínez et al., 2007). Regarding nymphal feeding, the diets of $C$. mitis in the Sierra Nevada (López-Rodríguez et al., 2008), $C$. petitpierreae in the Rif (Morocco) (Azzouz \& Sánchez-Ortega, 2000) and Serranía de Ronda (Navarro-Martínez et al., 2007) and C. libera in the Sierra de Huétor (Spain) (López-Rodríguez $\&$ Tierno de Figueroa, 2008) are known.

Capnioneura gelesae is an endemic species in the Iberian Peninsula that has only been reported in the Sierra Morena, the Montes de Toledo, the Sierra de Guadalupe and Algarve and is usually collected between 100 and $700 \mathrm{~m}$ a.s.l. (Tierno de Figueroa et al., 2003). Both males and females of this species were described by Berthémely and Baena (1984), but the nymph was not described until fifteen years later (Luzón-Ortega et $a l .$, 1999). Data on the biology of this species are very scarce. The flight period spans from November to March (Tierno de Figueroa et al., 2003). According to Gallardo Mayenco (1990), the nymph has been collected in different microhabitats, mainly in sand without vegetation and among boulders with vegetation. The male drumming call of this species was recently described, 


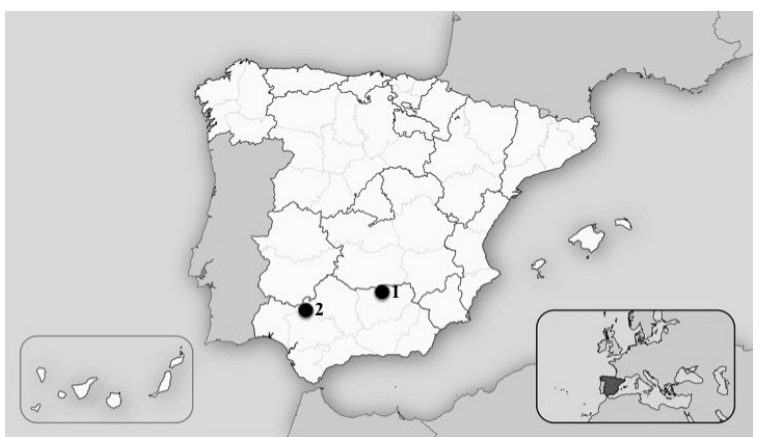

Figure 1. Map of Spain showing the sampling sites. Río Despeñaperros (1) and Arroyo del Moro (2). Mapa de España donde se muestran los sitios de muestreo. Río Despeñaperros (1) y Arroyo del Moro (2).

and it consists of $16.2 \pm 8.8$ beats with $689 \pm$ $7 \mathrm{~ms}$ interbeat intervals and a total duration of $10,614 \pm 6180 \mathrm{~ms}$ (Tierno de Figueroa et al., 2011a).

The aims of the present study are 1) to describe the life cycle of this species in two different temporary streams of the Sierra Morena; 2) to describe the nymphal diet in both streams; 3) to detect possible variations in the diet during ontogenetic development; and 4) to discuss the obtained results in relation to those previously found in other stonefly species, particularly those belonging to the Capnioneura genus.

\section{MATERIALS AND METHODS}

Sampling was carried out in Río Despeñaperros (Sierra Morena, Jaén, Spain; coordinates: $38^{\circ} 22^{\prime} 19^{\prime \prime} \mathrm{N} 3^{\circ} 30^{\prime} 33^{\prime \prime} \mathrm{W}, 560 \mathrm{~m}$ a.s.l.) and in Arroyo del Moro (Sierra Morena, Sevilla, Spain; co- ordinates: $38^{\circ} 02^{\prime} 26^{\prime \prime} N 5^{\circ} 56^{\prime} 13^{\prime \prime} \mathrm{W}, 349 \mathrm{~m}$ a.s.1.), two Mediterranean seasonal streams (Fig. 1). Macroinvertebrate samples were collected monthly from November 2006 to May 2007 and biweekly in June, just before the summer drought, in Río Despeñaperros, and from October 2014 to May 2015 in Arroyo del Moro, coinciding with the wet period of both streams. Both hydrological years were comparable in terms of precipitation and mean temperature. During each sampling date, we recorded in situ physical parameters, such as temperature, $\mathrm{pH}$, dissolved oxygen, conductivity and discharge by means of a multiparametric probe and a propeller meter (Table 1).

During the sampling period, the width of the wet channel in Río Despeñaperros varied from 2.95 to $5.35 \mathrm{~m}$, and the depth ranged from 0.04 to $0.31 \mathrm{~m}$. The substrate was composed of approximately $85 \%$ rocks and stones, $10 \%$ gravel and 5\% sand and silt. There were some branches and trunks on the riverbed. In Arroyo del Moro, the width of the wet channel varied from 1.00 to $3.30 \mathrm{~m}$, with a depth ranging from 0.04 to $0.37 \mathrm{~m}$. The substrate was composed of approximately $80 \%$ rocks and stones, $15 \%$ gravel and $5 \%$ sand and silt. There were some detritus, branches and trunks on the riverbed. In both streams, Ranunculaceae and Nasturtium sp. were common in some seasons. Mosses were absent at the sampling sites, and riparian vegetation was abundant and mainly consisted of Nerium oleander, Fraxinus sp., Berberis sp., Poaceae, Umbelliferae and Compositae.

We collected samples using either a Surber $\left(0.09 \mathrm{~m}^{2}\right.$ area and $250 \mu \mathrm{m}$ mesh size) or a kick sampler. In the latter case, a semi-quantitative ap-

Table 1. Main physico-chemical characteristics of the studied streams during the sampling periods. SD: standard deviation; Min: minimum; Max: maximum. Principales características físico-químicas de los arroyos estudiados durante los períodos de muestreo. SD: desviación estándar; Min: mínimo; Max: máximo.

\begin{tabular}{lcccccccccc}
\hline & \multicolumn{4}{c}{ Río Despeñaperros } & \multicolumn{4}{c}{ Arroyo del Moro } \\
\hline & $\mathrm{N}$ & Mean & SD & Min & Max & N & Mean & SD & Min & Max \\
\hline $\mathrm{pH}$ & 9 & 8.24 & 0.34 & 7.61 & 8.79 & 7 & 7.85 & 0.43 & 7.31 & 8.47 \\
$\mathrm{O}_{2}(\% \mathrm{sat})$ & 9 & 69.11 & 23.75 & 13.00 & 92.00 & 7 & 95.54 & 9.06 & 80.30 & 110.70 \\
$\mathrm{O}_{2}(\mathrm{mg} / \mathrm{l})$ & 9 & 7.03 & 2.73 & 1.10 & 9.70 & 7 & 9.58 & 1.12 & 7.64 & 11.19 \\
Temperature $\left({ }^{\circ} \mathrm{C}\right)$ & 9 & 13.62 & 4.34 & 7.75 & 19.65 & 7 & 12.70 & 2.93 & 6.90 & 16.30 \\
Conductivity $(\mu \mathrm{S} / \mathrm{cm})$ & 9 & 454.89 & 69.43 & 359.00 & 553.00 & 7 & 294.60 & 58.72 & 204.30 & 356.50 \\
Discharge $\left(\mathrm{m}^{3} / \mathrm{s}\right)$ & 9 & 0.10 & 0.11 & 0.00 & 0.32 & 7 & 0.23 & 0.29 & 0.00 & 0.82 \\
\hline
\end{tabular}


proach was employed, sampling approximately $0.125 \mathrm{~m}^{2}$. In both cases, several replicates were collected in different microhabitats (defined by the hydrological conditions and the substrate type) and pooled together in order to have a proper representation of the entire community of the studied section. The samples were preserved and brought to the laboratory, where they were
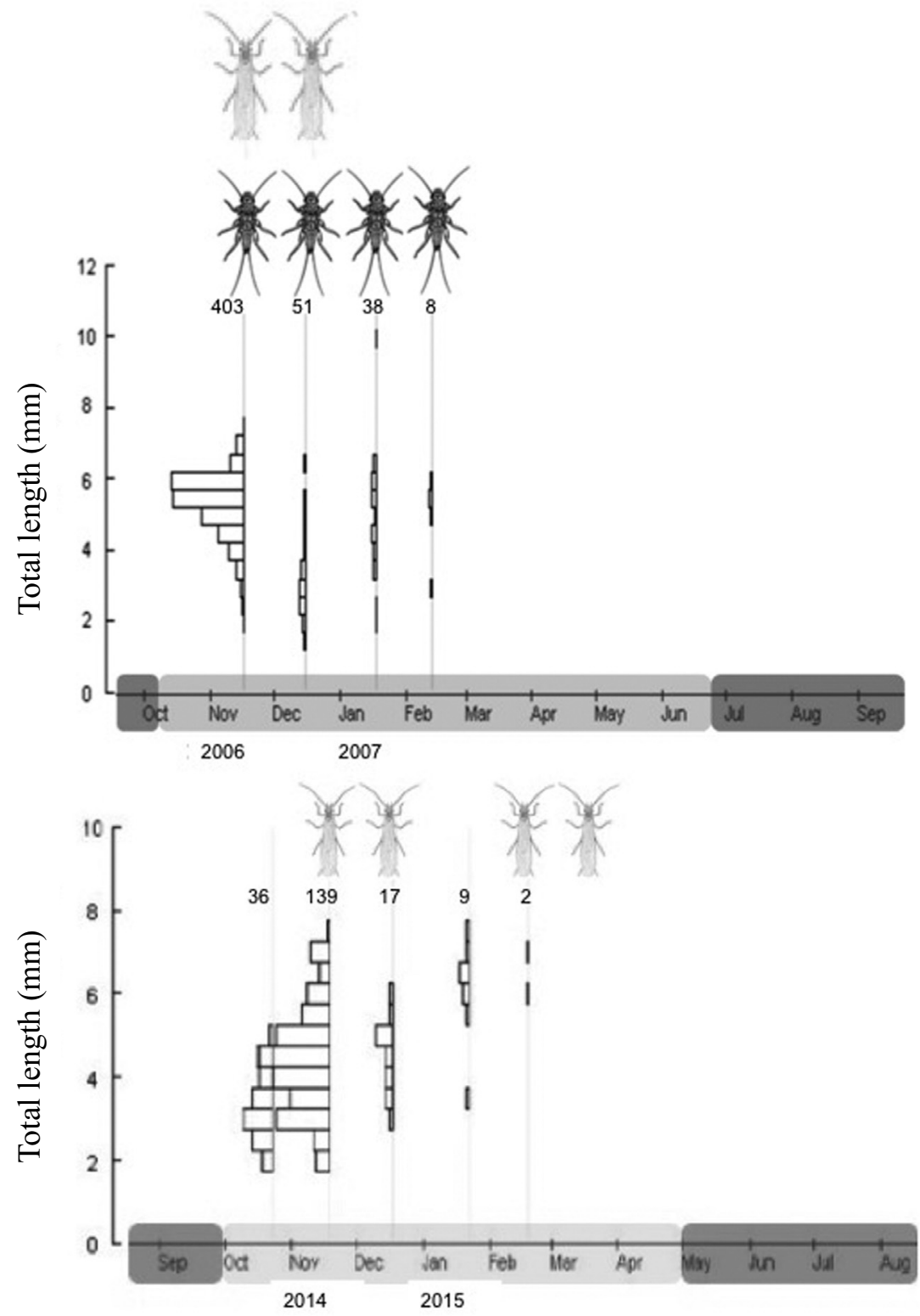

Figure 2. Life cycle of Capnioneura gelesae in Río Despeñaperros (top) and in Arroyo del Moro (bottom). The pale grey colour along the $X$ axis represents the period with water in the channel. Drawings of nymphs and adults represent captures of mature nymphs (only represented in the graph of Río Despeñaperros) and adults, respectively. Bar width represents the abundance of nymphs in each size class. Numbers at the top of each column indicate the total number of individuals captured on that date. Ciclo de vida de Capnioneura gelesae en Río Despeñaperros (arriba) y en Arroyo del Moro (abajo). El color gris claro en el eje X representa el periodo con agua en el cauce. Los dibujos de ninfas y adultos representan capturas de ninfas maduras (solo representadas en el gráfico del Rio Despeñaperros) y adultos, respectivamente. El ancho de las barras representa la abundancia de ninfas de cada clase de tamaño. Los números sobre las columnas indican el número total de individuos capturados en esa fecha. 
sieved. Stoneflies were sorted and identified to species.

To represent the life cycle of $C$. gelesae, we measured the total body length of 30 individuals every month, when possible, using a micrometer inserted into the eyepiece of a binocular microscope $(0.01 \mathrm{~mm}$ accuracy). After that, individuals were separated into $0.5 \mathrm{~mm}$ intervals. The size-frequency graphs representing the life cycles were made with FiSAT II software (Gayanilo $e t$ al., 2002).

The diet of the nymphs was studied by observing the gut contents of individuals of different sizes using the methodology of Bello and Cabrera (1999), as in other studies of stonefly feeding (e.g., Tierno de Figueroa et al., 2006, Navarro-Martínez et al., 2007, López-Rodríguez et al., 2009a). Each individual was placed into a vial with Hertwig's liquid and heated in an oven at $65{ }^{\circ} \mathrm{C}$ for approximately 24 hours. The specimens were then mounted on slides for study under the microscope. We estimated the absolute percentage of gut content inside the digestive tract (at $40 \times$ ) as the total area occupied by the content in the whole digestive tract and the relative gut content (at $400 \times$ ) as the area occupied by each component within the total gut content using a microscope with an ocular micrometer. Each population of the studied species was classified into a functional feeding group (FFG) according to food sources and mechanisms of food acquisition (Cummins, 1973; Merritt \& Cummins, 2006). To study the correlation between the size of the nymphs and gut contents, we used a gamma correlation test with STATISTICA software (Statsoft, 2005). A non-parametric test was used because the data did not fit a normal distribution (Kolmogorov-Smirnov test, $p<0.05$ in all cases).

\section{RESULTS AND DISCUSSION}

\section{Life cycle}

A total of 500 nymphs of $C$. gelesae were collected in Río Despeñaperros between November 2006 and February 2007, and 203 nymphs were collected in Arroyo del Moro between October 2014 and February 2015.

Both populations have a univoltine life cycle of similar duration (five and four months, respectively) with a long emergence period (Fig. 2). Hatching seems to begin very rapidly after water arrival to the stream channel and lasts for at least two months, although the highest number of nymphs appears at the beginning of the developmental period, approximately one month after the arrival of water. This may reflect very fast growth in this species, which is also supported by the fact that mature nymphs and/or adults are present at this time. Due to the delay in the hatching of some eggs, nymphs of several sizes are present during almost the entire developmental period, reflecting the coexistence of different cohorts. Thus, mature nymphs and/or adults are present during the entirety of this period, and both populations have a relatively long flight period, coinciding with the period already noted for this species in other areas (Tierno de Figueroa et al., 2003). After mating, the females would lay eggs in the stream, and the eggs would probably pass through a resting stage to cope with the dry period. Subsequently, the eggs would develop quickly when the water arrives in the channel the next autumn. Thus, the already mentioned delay in egg hatching would act as a security mechanism in years when the stream receives water during an anomalous rainy period at the beginning of autumn and then dries again. Adverse conditions under this scenario would generate high nymphal mortality, but those from eggs with delayed hatching would survive, and the population would persist in time, although likely with a lower abundance.

According to the classification of Hynes (1970), this species has a "fast seasonal" life cycle with a probable egg diapause. This kind of life cycle also appears in other species of the Capnioneura genus, such as C. mitis Despax, 1932 (Sánchez-Ortega \& Alba-Tercedor, 1990; López Rodríguez et al., 2008) and C. petitpierreae Aubert, 1961 (Navarro-Martínez et al., 2007), the latter of which is also a typical inhabitant of temporary waters. Opposite to the univoltine life cycle pattern found within the genus, $C$. brachyptera Des- 
pax, 1932 has a two-year life cycle at high altitudes in the Pyrenees (Lavandier, 1975), which could be a consequence of the effect of lower temperatures on the development of these organisms.

Other Nemouroidea stoneflies of temporary waters also present a similar life cycle with a fast developmental period, such as Nemoura lacustris Pictet, 1865 (López-Rodríguez \& Tierno de Figueroa, 2005), Rhabdiopteryx christinae Theischinger, 1975 (López-Rodríguez \& Tierno de Figueroa, 2006) and Brachyptera vera cordubensis Berthélemy \& Baena, 1984 (López-Rodríguez et al., 2009a). This convergence in the life cycles of these distantly related species highlights the importance of environmental conditions in the modulation of the strategies of these species and the constraints the habitat imposes on them.

\section{Nymphal feeding}

A total of 94 individuals of $C$. gelesae in Río Despeñaperros and 66 in Arroyo del Moro were used to study the gut contents. In Río Despeñaperros, the guts were empty in 34 nymphs, while in the Arroyo del Moro population, 16 individuals with empty guts were present. In the former population, the main gut content component was diatoms, followed by fine particulate organic matter (FPOM). No pollen was detected in the guts of these nymphs, but fungi, coarse particulate organic matter (CPOM) and Cyanoprokaryota were occasionally recorded (Table 2). In Arroyo del Moro, FPOM was the most abundant trophic resource in the digestive tracts of the studied nymphs (Table 2). Fungi were also relatively well represented in the guts, while CPOM and pollen, the other two trophic resources recorded in this population, were only occasionally found. Thus, the first population can be classified as scrapers and gatherer-collectors, following the functional feeding groups (FFG) of Merritt \& Cummins (2006), and the second as gatherer-collectors. Differences in the feeding habits of the two groups of nymphs can be related to the availability of resources: diatoms, particularly those belonging to the genus Melosira, were tremendously abundant in Río Despeñaperros during the sampling period, so this could result in a nutrient-rich resource that is easy to obtain for the nymphs in this stream.

On the other hand, the correlation between size and the percentages of the different food items in the guts of the nymphs was studied to assess possible variations in the diet with size. For the population from Río Despeñaperros, a significant negative correlation was detected between size and fungi, while a significant positive correlation between size and CPOM content was found in the population from Arroyo del Moro (Table 3). This would suggest that in the former population, larger nymphs feed less on fungi, while in the latter population, larger nymphs feed more on CPOM, but these results should be taken with caution due to the low percentage of nymphs with these resources in their guts (these correlations could be an artefact of the data).

Other previously studied species of the family Capniidae also show differences in their feeding habits. For instance, C. mitis in perma-

Table 2. Results of the gut content analyses performed for the nymphs from each sampling site. SD: standard deviation; Min: minimum; Max: maximum; FPOM: fine particulate organic matter; CPOM: coarse particulate organic matter; FFG: functional feeding group. Resultados de los análisis de contenidos digestivos llevados a cabo en las ninfas de cada sitio de muestreo. SD: desviación estándar; Min: mínimo; Max: máximo; FPOM: materia orgánica particulada fina; CPOM: materia orgánica particulada gruesa.

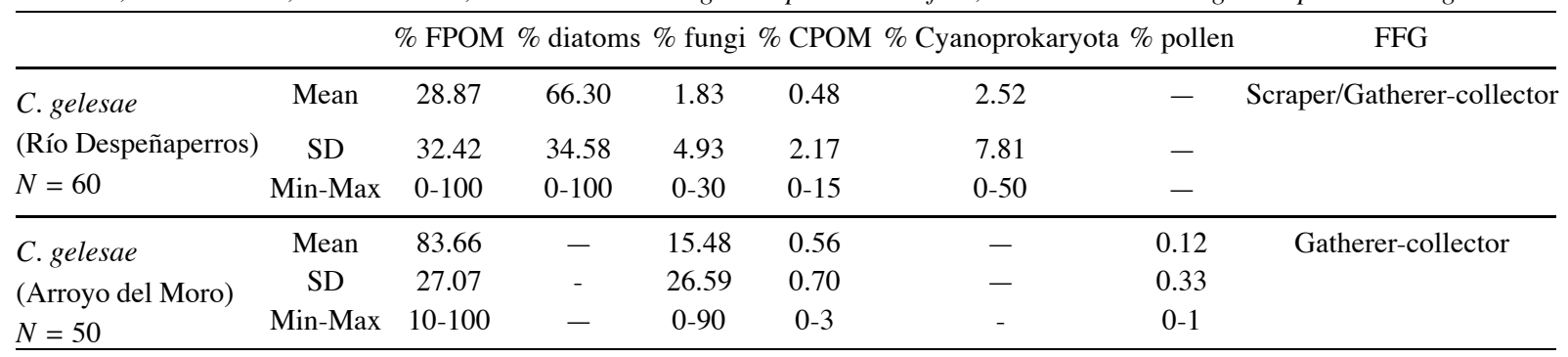


Table 3. Values of the Gamma correlations between gut contents and size of the nymphs from each studied population. Significant results are marked with an asterisk. FPOM: fine particulate organic matter; CPOM: coarse particulate organic matter. Valores de la correlación Gamma entre contenidos digestivos y tamaño de las ninfas de cada población estudiada. Los resultados significativos están marcados con un asterisco. FPOM: materia orgánica particulada fina; CPOM: materia orgánica particulada gruesa.

\begin{tabular}{lcc}
\hline & $\begin{array}{c}\text { C. gelesae } \\
\text { total length }(\mathrm{mm}) \\
\text { Río Despeñaperros }\end{array}$ & $\begin{array}{c}\text { C. gelesae } \\
\text { total length }(\mathrm{mm}) \\
\text { Arroyo del Moro }\end{array}$ \\
\hline \% FPOM & -0.08 & -0.16 \\
\% diatoms & 0.10 & - \\
$\%$ hyphae & -0.17 & 0.13 \\
$\%$ fungi & $-0.29^{*}$ & $0.38^{*}$ \\
$\%$ CPOM & 0.21 & - \\
\% Cyanoprokaryota & -0.24 & -0.12 \\
\% pollen & - & \\
\hline
\end{tabular}

nent streams feed mainly on CPOM but also incorporate certain quantities of diatoms into their diets, behaving mainly as shredders but also as scrapers (López Rodríguez et al., 2008), while in temporary streams, C. petitpierreae (NavarroMartínez et al., 2007), C. libera and Capnopsis schilleri (Rostock, 1892) (López-Rodríguez \& Tierno de Figueroa, 2008) behave as gatherercollectors. As mentioned before, this could be a consequence of the particular characteristics of the habitat they inhabit and the available resources more than a phylogenetic, species-specific difference.

\section{CONCLUSIONS}

In light of these results and the comparisons between the two populations and among them and other species of the Capniidae family, we can conclude that this family is quite heterogeneous in terms of life strategies. The fact that the two populations of $C$. gelesae have a similar life cycle in relatively distant streams lets us suppose that this trait is characteristic of the species and has allowed it to colonize these temporal habitats, but the comparison among different species of the genus Capnioneura also provides evidence to support an important role of environmental constraints in shaping their strategies. Thus, a trade-off between environmental conditions and the evolutionary histories of these organisms has likely provided the proper scenario in the past to allow them to colonize and succeed in the habitats they currently occupy.

\section{ACKNOWLEDGEMENTS}

Part of this study has been made in the framework of the project Estudio de la variabilidad del indice de macroinvertebrados (IBMWP) en los ríos de Sierra Morena sometidos a sequía estival. Clave: $C U(P H)-5384$, funded by Confederación Hidrográfica del Guadalquivir (Spain) and realized by Hydraena S.L.L.

\section{REFERENCES}

AGÜERO-PELEGRÍN, M. \& M. FERRERASROMERO. 2002. The cycle of Guadalgenus franzi (Aubert, 1963) (Plecoptera: Perlodidae) in the Sierra Morena Mountains (southern Spain): semivoltinism in seasonal streams of the Mediterranean Basin. Aquatic Insects, 24: 237-245.

AUBERT, J. 1963. Les Plécoptères des cours deau temporaires de la péninsule ibérique. Mitteilungen der Schweizerischen Entomologischen Gesellschaft, 25: 301-315.

AZZOUZ, M. \& A. SÁNCHEZ-ORTEGA. 2000. Feeding of the nymphs of nine stonefly species (Insecta: Plecoptera) from North Africa (Rif Mountains, Morocco). Zoologica baetica, 11: 35-50.

BELLO, C.L. \& M.I. CABRERA. 1999. Uso de la técnica microhistológica de Cavender y Hansen en la identificación de insectos acuáticos. Boletín Entomológico Venezolano, 14(1): 77-79.

BERTHÉLEMY, C. \& M. BAENA. 1984. On some plecoptera from southern Spain. Annales de Limnologie, 20 (1-2): 21-24.

CUMMINS, K.W. 1973. Trophic relations of aquatic insects. Annual Review of Entomology, 18: 183-206.

DEWALT, R.E., M.D. MAEHR, U. NEU-BECKER \& G. STUEBER. 2016. Plecoptera Species File Online. Version 5.0/5.0. [retrieval date: August, $\left.23^{\text {rd }}, 2016\right]$. http://Plecoptera.SpeciesFile.org. 
GALLARDO MAYENCO, A. 1990. Distribución de los plecópteros en el río Guadiamar (Sevilla). Ecología, 4: 333-337.

GAYANILO, JR. F.C., P. SPARRE \& D. PAULY. 2002. FiSAT II (ver. 1.2.0.). Food and Agriculture Organization of the United Nations (FAO) (www. fao.org/fi/statist/fisoft/fisat/index.htm).

HYNES, H.B.N. 1970. The ecology of running waters. Liverpool University Press. Liverpool. UK.

HYNES, H.B.N. 1976. Biology of Plecoptera. Annual Review of Entomology, 21: 135-153.

LAVANDIER, P. 1975. Cycle biologique et production de Capnioneura brachyptera D. (Plécoptères) dans un ruisseau d'altitude des Pyrénées centrales. Annales de Limnologie, 11: 145-156.

LÓPEZ-RODRÍGUEZ, M.J. \& J.M. TIERNO DE FIGUEROA. 2005. Ciclo de vida y composición de la dieta de Nemoura lacustris Pictet, 1865 (Plecoptera, Nemouridae). Boletín de la Asociación Española de Entomología, 29: 87-97.

LÓPEZ-RODRÍGUEZ, M.J. \& J.M. TIERNO DE FIGUEROA. 2006. Life cycle and nymphal feeding of Rhabdiopteryx christinae Theischinger, 1975 (Plecoptera, Taeniopterygidae). Annales de la Société Entomologique de France, 42: 57-61.

LÓPEZ-RODRÍGUEZ, M.J. \& J.M. TIERNO DE FIGUEROA. 2008. Feeding habits of two capniidae (Plecoptera) species from Southern Iberian Peninsula. Journal of Entomological Science, 43(1): 141-142.

LÓPEZ-RODRÍGUEZ, M.J., J.M. TIERNO DE FIGUEROA \& J. ALBA-TERCEDOR. 2008. Life history and nymphal feeding of some species of Ephemeroptera and Plecoptera (Insecta) in Sierra Nevada (Southern Iberian Peninsula). Hydrobiologia, 610: 277-295.

LÓPEZ-RODRÍGUEZ, M.J., J.M. TIERNO DE FIGUEROA \& J. ALBA-TERCEDOR. 2009a. Life history, feeding and secondary production of two Nemouroidea species (Plecoptera, Insecta) in a temporary stream of the Southern Iberian Peninsula. Fundamental and Applied Limnology-Archiv für Hydrobiologie, 175 (2): 161-170.

LÓPEZ-RODRÍGUEZ, M.J., J.M. TIERNO DE FIGUEROA, S. FENOGLIO, T. BO \& J. ALBATERCEDOR. 2009b. Life strategies of 3 Perlodidae species (Plecoptera, Insecta) in a Mediterranean seasonal stream of Southern Europe. Journal of the North American Benthological Society, 28(3): 611-625.
LUZÓN-ORTEGA, J.M. 2002. Contribución al conocimiento de los plecópteros (Insecta, Plecoptera) del sur de la Península Ibérica. Ph.D. Thesis. University of Granada, Spain.

LUZÓN-ORTEGA, J.M, J.M. TIERNO DE FIGUEROA \& A. SÁNCHEZ-ORTEGA. 1999. The nymphs of Capnioneura Ris, 1905 (Plecoptera, Capniidae) of the Iberian Peninsula and North Africa. Description of C. gelesae Berthélemy \& Baena, 1984 and C. libera (Navás, 1909) nymphs. Annales de la Société Entomologique de France, 35(3-4): 295-301.

MERRITT, R.W. \& K.W. CUMMINS. 2006. Trophic relations of macroinvertebrates. In: Methods in Stream Ecology. 2nd ed. F. R. Hauer \& G. A. Lamberti (eds.); 585-610. Academic Press, New York. EEUU.

NAVARRO-MARTÍNEZ, D., M.J. LÓPEZ-RODRÍGUEZ \& J.M. TIERNO DE FIGUEROA. 2007. Life cycle and nymphal feeding of Capnioneura petitpierreae Aubert, 1961 (Plecoptera, Capniidae). Illiesia, 3(8): 65-69.

SÁNCHEZ-ORTEGA, A. \& J. ALBA-TERCEDOR. 1990. Life cycles of some species of Plecoptera in Sierra Nevada (South of Spain). In: Mayflies and Stoneflies: Life History and Biology. I. C. Campbell (ed.): 43-52. Kluwer Academic. Dordrecht. Netherlands.

SANZ, A., C. TRENZADO, M.J. LÓPEZ-RODRÍGUEZ, M. FURNÉ \& J.M. TIERNO DE FIGUEROA. 2010. Study of the antioxidant defense in four species of Perloidea (Insecta, Plecoptera). Zoological Science, 27(12): 952-958.

STATSOFT, INC. 2005. STATISTICA (data analysis software system), version 7.1. (www.stasoft.com).

TIERNO DE FIGUEROA, J.M., A. SÁNCHEZ-ORTEGA, P. MEMBIELA-IGLESIA \& J.M. LUZÓN-ORTEGA. 2003. Plecoptera. In: Fauna Ibérica, vol. 22. M.A. Ramos et al. (eds.). Museo Nacional de Ciencias Naturales. CSIC. Madrid. Spain.

TIERNO DE FIGUEROA, J.M., A. VERA \& M.J. LÓPEZ-RODRÍGUEZ. 2006. Adult and nymphal feeding in the stonefly species Antarctoperla michaelseni and Limnoperla jaffueli from Central Chile (Plecoptera: Gripopterygidae). Entomologia Generalis, 29(1): 39-45.

TIERNO DE FIGUEROA, J.M., J.M. LUZÓN-ORTEGA \& M.J. LÓPEZ-RODRÍGUEZ. 2011a. Intraspecific and interspecific variation in drumming signals in the genus Capnioneura (Plecoptera: Capniidae). Aquatic Insects, 33(4): 335-341. 
TIERNO DE FIGUEROA, J.M., C.E. TRENZADO, M.J. LÓPEZ-RODRÍGUEZ \& A. SANZ. 2011b. Digestive enzyme activities of two stonefly species (Insecta, Plecoptera) and their feeding habits. Comparative Biochemistry and Physiology A, 160: 426-430.
TIERNO DE FIGUEROA, J.M., M.J. LÓPEZ-RODRÍGUEZ, S. FENOGLIO, P. SÁNCHEZ-CASTILLO \& R. FOCHETTI. 2013. Freshwater biodiversity in the rivers of the Mediterranean Basin. Hydrobiologia, 719: 137-186. 